\title{
YENI ILETIŞiM TEKNOLOJILERINI SORGULAMAK: ETIK, GÜVENLIK VE MAHREMIYETIN KESIŞTiĞi NOKTA
}

\author{
Selin BiTiRIM OKMEYDAN ${ }^{1}$
}

\begin{abstract}
Öz
Teknoloji, insan hayatını büyük ölçüde kolaylaştıran, dönüştüren ve geliştiren bir olgu olarak tanımlanabilmektedir. Teknoloji alanında ortaya çıkan her yenilik ve devinim, devrim niteliği taşımakta ve insanı kuşatan ekonomik, politik ve sosyo-kültürel alanlarda radikal kopuşları da beraberinde getirmektedir. Bu kopuşların uzantısı olarak insan hayatına yön veren paradigmalar da değişmekte, evrilmekte ve insan hayatını kökten etkileyecek teknolojik gelişmeleri yeniden üretmektedir. İnsanoğlu bu sözü edilen çift yönlü etkileşim süreci içerisinde varlığını sürdürmekte ve teknolojik gelişmeleri kendi yararı doğrultusunda dizginlemeye çalışmaktadır. Ancak küreselleşmenin etkilerinin somut olarak görülmeye başlandığı bu çağda teknolojiyi insan yararına kullanmak her zaman düşünüldüğü kadar kolay olmamaktadır. Teknolojik gelişmeler, teori ve pratikte birçok soruna yol açmanın yanı sıra, kişisel mahremiyeti de zedeleyebilmektedir.

$\mathrm{Bu}$ çalışmanın temel amacı; yeni iletişim teknolojilerinin karmaşık doğasını eleştirel bir bakış açısı ile değerlendirmek ve bu teknolojilerin bireysel/toplumsal yaşama yansımalarını etik, güvenlik ve mahremiyet bağlamında tartışmaktır. Bu temel amaç doğrultusunda çalışmanın yöntemi, literatür taramasına dayandırılmıştır. Yeni iletişim teknolojilerini sorgulayarak etik, güvenlik ve mahremiyet gibi birbirinden ayrı düşünülemeyen tartışmalı konulara dikkat çeken çalışmada, bu teknolojilerin sözü edilen alanlarda önemli açmazları bulunduğu sonucuna ulaşı1mıştır.
\end{abstract}

Anahtar Kelimeler: Yeni iletişim teknolojileri, etik, belirsizlik, güvenlik ve mahremiyet

\section{QUERYING OF NEW COMMUNICATION TECHNOLOGIES: INTERSECTION POINT OF ETHICS, SECURITY AND PRIVACY}

\begin{abstract}
Technology has been defining as a fact that makes life easier by transforming, developing, and converting it. Every innovation and movement which occurs in the field of technology, has the characteristics of revolution. This situation brings together with radical changes surrounding human being in the economic, political, and socio-cultural areas. As an extension of these changes, the paradigm that giving direction to the human life, are also changed and as a result of that, technological changes which will radically effect the life of people, has been reproducing in the process of two-way interaction. Mankind is making his existance continue and trying to design the technological developments for his own benefit. In our era, however the effects of globalisation have already started seeing as concrete, but using the technology for the benefit of people is being not easy as it always thought. Technologic development causing to many problems in theory and practice, can be bruising personal privacy at the same time.
\end{abstract}

\footnotetext{
${ }^{1}$ Arş. Gör. Dr., Ege Üniversitesi Illetişim Fakültesi Halkla İlişkiler ve Tanıtım Bölümü, selin.bitirim@ege.edu.tr
} 
The basic purpose of this study is to evaluate its complicated nature of these technologies, with a critical perspective and is to discuss its reflections to the individual/social life in the contex of ethics, and privacy. The method of study towards this main purpose is based on literature review. In the result of this study that takes attention to the controversial and non-separable issues such as ethics, and privacy that are caused by the new communication technologies, have been reached to the serious dilemmas of these technologies.

Key Words: New communication technologies, ethics, uncertainty, security and privacy

Giriş

"İnsana Cennete girmesi için bir anahtar verilmiştir, aynı anahtar Cehennemin Kapısını da açar" Budist Özdeyişi

Teknolojinin, insanoğlunun var olduğu günden bu yana, tüm yaşam evrelerinde temel belirleyici dinamik olarak hüküm sürdüğü bilinmektedir. Tartışmasız, insan hayatının her alanını kapsayan klasik kavram ve olgular, küreselleşme sürecinin radikal değişim hareketlerine koşut olarak dönüşmektedir. İnsanın var oluşu ile birlikte çevresini dizginleyebilmek için yarattığı teknolojik yeniliklerin her biri, kendi çağı içerisinde birer devrim niteliği taşımaktadır. Ancak yine de daha önce hiçbir teknolojik devrimin, insan hayatını günümüzdeki kadar kökten dönüştürme ve yeniden kurgulama potansiyeline sahip olmadığını söylemek mümkündür. Küreselleşen dünyada bilgi merkezli şekillenen ve bilgiyi kutsayan yeni iletişim teknolojileri, farklı bir toplumsal yapı ve anlayışa dayanarak ortaya çıkmıştır. Ancak bu teknolojiler tarafından oluşturulan yeni toplumsal yapının kuralları ve davranış kalıpları küresel çapta tam olarak özümsenmiş değildir. Bu nedenle yeni iletişim teknolojileri tarafindan belirlenen toplumsal yaşantıda bir kaos görüntüsü hüküm sürmektedir.

Bir toplumda hangi davranışların etik olup olmadığı, tartışmalı ve göreceli olarak daha bilinir olsa da etik davranışın sınırlarını çizmek ve etiğin nerede başlayıp bittiğini söylemek oldukça zordur. Bu nedenle yeni iletişim teknolojilerine ilişkin; yasalarla güvence altına alınmaya ve korunmaya çalışılan özel hayata dair denetleme ve düzenleme pratikleri nereye kadar etiktir? Evrensel etikten feragat edilerek gönüllü olarak kabul edilen bu yasal düzenlemeler, nereden başlayarak kişisel mahremiyeti ihlal etmektedir? Tüm bu düzenlemeler, dijital dünyada suç işlenmesini 
önlemek ve kişisel güvenliği sağlamak için yeterli midir? Yeterli değilse neler yapılmalıdır?, gibi sorulara yanıt bulmak; her geçen gün daha çok kişinin ilgisini çekmekte ve özellikle yeni iletişim teknolojileri ekseninde ele alınan mahremiyet bağlamında ve bu bağlamı çerçeveleyen etik ve güvenliğe ilişkin temel sorunlar arasında yer almaktadır.

Yeni iletişim teknolojileri izleğinde çalışmanın nihai eksenini oluşturan mahremiyet olgusuna yönelik bir sorgulama, dijitalleşme kapsamında yeniden ve mutlak şekilde değerlendirilmesi gereken etik ile bilgi güvenliğinin sağlanmasını ve kişisel bilgilerin korunmasını içeren güvenlik konusundan bağımsız değildir. $\mathrm{Bu}$ nedenle yeni iletişim teknolojilerinin mahremiyet bağlamındaki sorgulamasına; etik ve güvenlik konularını dahil etmek, bu çalışmanın amacı doğrultusunda genel bir perspektif kazanmasına yardımcı olacak bir unsur olarak görülmektedir. Gerek etik, gerekse güvenlik ve mahremiyet konularının her biri, esasında tamamen birbiri ile kesişen tümel bir çalışma evrenini ifade etmekte ve içermektedir. Ancak bilindiği gibi, her çalışmanın amacı; aynı zamanda çalışmanın kapsamını belirlemekte ve çalışmayı sınırlandırıcı bir nitelik taşımaktadır. O halde etik, güvenlik ve mahremiyet temalarının tüm yönleri ile betimleyici ve değerlendirici bir şekilde ele alınması, başka bir çalışmanın konusu olarak düşünülmelidir. Çünkü bu çalışmanın amacı; etik, güvenlik ve mahremiyet konularını özel ve derinlikli bir şekilde incelemek değil, yeni iletişim teknolojilerini mahremiyetin tikel bileşenleri olan etik ve güvenlik ekseninde temel yönlerden sorgulayarak bu teknolojilerin olumlu ve olumsuz sonuçları üzerinde yeniden düşünmeye sevk etmektir.

$\mathrm{Bu}$ doğrultuda, çalışmanın amacını gerçekleştirmeye yönelik, literatür taraması yönteminden yararlanılmıştır. Bilindiği gibi, literatür taraması yönteminin temel amacı; seçilen konunun önemini göstermek ve sonraki araştırmalara yön vermektir. Buna göre literatür taramasının işlevleri; konunun tanımlanıp sınırlandırılmasına yardımcı olmak, araştırmaya genel bir perspektif sunmak, araştırmada istenmeyen tekrarları önlemek, konunun önceki bilgiler ile ilişkilendirilmesine yardımcı olmak ve konu kapsamında gerçekleştirilecek yeni çalışmaların yolunu açmaktır (Balcı, 2005: 57). Literatür taramasında birincil ve ikincil kaynaklardan yararlanmak mümkün olsa da bu yöntemin aslı, birincil 
kaynakları vurgulamak ve konu kapsamında mevcut bilgileri aktarmaktır. Ayrıca literatür taraması yönteminin kullanılması, çalışmanın izleğinde olumlu ve olumsuz görüşleri bütüncül ve genel bir perspektif ile aktarmayı zorunlu kılmaktadır. Bu nedenle çalışma ekseninde yeni iletişim teknolojilerini sorgulamaya geçmeden önce, bu teknolojilerin kapsamı ve özelliklerine yer verilmesi gerekmektedir.

\section{Yeni İletişim Teknolojilerinin Kapsamı}

Günümüz dünyası hızlı bir değişim trendiyle karşı karşıyadır. Tüm paradigmaları dönüştüren ve yeniden tanımlayan bu trendin en büyük öznelerinin ise teknoloji ve küreselleşme süreci olduğunu ifade etmek mümkündür. Pozitivist açıdan insan hayatını her yönüyle kolaylaştıran teknoloji, toplumsal yaşam bağlamında hızlı değişimleri ve eski bağlardan radikal kopuşları da beraberinde getirmektedir. Yeni iletişim teknolojilerindeki ivme, bilginin adem-i merkeziyetçi (merkezsiz) bir yapıya kavuşması ile zaman ve mekan engeli olmaksızın dünyanın bir ucundan bir ucuna eş zamanlı dolaşımını sağlarken; bilgi güvenliğinin yok olmasına ve kişisel mahremiyetin kaybolmasına ilişkin birçok eleştirel teorinin ortaya atılmasına da zemin hazırlamaktadır. Yeni iletişim teknolojilerinin bu çift yönlü doğasını daha rahat anlayabilmek için, bu teknolojilerin geçmiş ve günümüz ekseninde irdelenmesinin çalışmanın geneline 1şık tutacağı düşünülmektedir.

Yeni iletişim teknolojilerinin kapsamı gün geçtikçe genişlemekte ve bu teknolojileri besleyen faktörler de her geçen gün artış göstermektedir. Bugün "internet, intranet ve extranet, ofis otomasyon sistemleri, fonksiyonel bilişim sistemleri, yönetim bilişim sistemleri, uzman sistemler, karar destek sistemleri ve elektronik veri değişim sistemleri” (Elibol, 2005: 158-159) yeni iletişim teknolojileri arasında değerlendirilmektedir. Görüldüğü gibi, bu teknolojilerin kapsamı oldukça geniş bir yelpazeyi içermekte ve iletişim dünyasında önemli rol oynamaktadır. Bugün kullanılan anlamıyla yeni iletişim teknolojileri; “İletişim Uyduları, TeletextVideotext (Ekran Gazetesi), Viewdata (Videoyazım), Kablolu Televizyon, İki Yönlü Televizyon, Cam (Fiberoptik) Kablo, Yüksek Tanımlamalı Televizyon, Tele-video, Video Diskler ve Video Disk Okuyucuları ve internet gibi çok geniş alanı içinde barındırmaktadır" (Vural, 2006: 4). Esasen yeni iletişim teknolojileri ile dijital iletişim sistemleri kastedilmektedir. "İletişim alanındaki teknolojik gelişmeler, dijital 
teknoloji ile fiber optik ve lazer teknolojisi sayesinde iletişimde ortaya çıkan yenilenmelerin ve büro donatımında yenilenme yaratan 'akıllı' terminal, telefon, faks ve diğer haberleşme donanımındaki gelişmelerle birlikte yaratılmıştır” (Erkan, 1998: 81). Bu teknolojilerin iletişim alanında kullanılarak toplumsal yaşama doğrudan yansıması ile birlikte Bilişim Çă̆ının da olanca hızıyla başladığı söylenebilmektedir.

Yeni iletişim teknolojileri niceliksel yönden kısa bir tarihe sahipse de; bu teknolojilerin niteliğinin, tüm yaşamı ve yaşam içerisindeki mekanizmaları değiştirip dönüştürmeye yetecek kadar kapsamlı olduğu ileri sürülebilmektedir. Dijitalleşmeye dayalı bu yeni teknolojilerin, özellikle iletişimin gelişmesi üzerinde önemli bir rol oynadı̆̆ı ifade edilebilmektedir. "Dijital iletişim, yakın zamana kadar (belli bir ölçüde bugün de) kullanılan ve elektromanyetik akımın değiştirilerek belirlenen bir frekans üzerinden bilgiler gönderilip alınmasını sağlayan analog sistemin yerine, iletişimin binary ad verilen yeni bir teknikle gerçekleştirilmesidir” (Yahyagil, 2001: 10). Dijital sistemlerin gelişimi ile ortaya çıkan yeni iletişim teknolojileri, her şeyin elektronikleştiği bir dünyanın da yaratıcısı olmaktadır. Bu kapsamda her geçen gün yeni bir elektronik kavram hayatımıza girmektedir. Öyle ki, elektronik birey (e-birey) ve elektronik devlet (e-devlet) hayal olmaktan çıkmakta ve tüm gerçekliğiyle karşımızda durmaktadır.

Ancak yeni iletişim teknolojileri toplumsal yaşamı saydamlaştırma ve şeffaflaştırma ekseninde; temelde mahremiyet ve bu kavramın ayrılmaz bileşenleri olan etik ve güvenliğe dair sorgulamaları ve çözüm bekleyen sorunları da kucaklayarak hayatımıza dahil olmaktadır. Örneğin, devletin de elektronikleşmesi ile birlikte kamusal hayatta ortaya çıkan şeffaflık, tarafsızlık gibi ilkelerin uygulanması bir yandan kolaylaşmakta; diğer bir yandan da dijital uçurum, güvenlik ve kişi mahremiyetinin azalması gibi yeni sorunlara kimlik kazandırmaktadır. Bilgi edinme ve kişisel gelişimi gözetme gibi en temel insan hak ve özgürlükleri içine kadar giren yeni iletişim teknolojileri, yadsınamayacak yararlarının yanında; bilinmezlik, belirsizlik ve güvensizlik gibi olumsuz çağrışımları da tetiklemektedir. Dolayısıyla bu tetiklemelerden kaynaklanabilecek kaos ortamını engellemek için; bu teknolojilere hukukî, politik ve sosyo-kültürel çok boyutlu düzenlemeler getirilmeye çalışılmaktadır. 


\subsection{Yeni İletişim Teknolojilerinin Özellikleri}

Kuşkusuz, içinde yaşadığımız çağa yön veren yeni teknolojilerin daha önceki teknolojilere benzeyen ve daha önce ortaya çıkan teknolojilerden kesin sınırlarla ayrılan büyük farkları bulunmaktadır. Her yeni teknolojik devinim gibi bu yüzyıla damga vuran teknolojik hareketler de etkileşimde bulunduğu bu çağ için bir devrim niteliği taşımaktadır. Yeni iletişim teknolojilerinin özelliklerine geçmeden önce genel anlamda teknolojinin özellikleri üzerinde durmanın, konunun bütününe 1şı tutması bakımından yararlı olacağı düşünülmektedir. Buna göre teknolojinin temel özellikleri şu şekilde sıralanabilmektedir (Williams, 1996: 3):

1. Teknoloji, insan potansiyelini genişletecek eylemleri içerir.

2. Teknoloji, insanların ihtiyaçlarına ve isteklerine yanıt verir.

3. İnsanlar teknolojiyi yaratır, uygular ve kullanır.

4. Teknoloji; araçların, makinaların, tekniklerin, sistemlerin ve teknik araçların kullanılması ile uygulanır.

5. Teknoloji, toplum ve kültürde var olur; her ikisinden etkilenir ve her ikisini etkiler.

6. Toplum, teknolojinin kullanımı ve kontrolünü sorgulama yeteneğine sahiptir.

7. Teknoloji, gelişmişlik düzeyine veya gelişim aşamasına bakmaksızın her kültürde belirgindir.

8. Teknoloji, insanların doğal çevre üzerinde kontrol sahibi olmasını sağlar.

9. Teknoloji, insan ırkının hayatta kalması için temeldir.

10. Teknoloji, gelecek yönelimlidir.

Buradan da görülebileceği gibi, teknolojinin temel özellikleri, yeni iletişim teknolojileri açısından da geçerliliğini korumaktadır. Ancak yeni iletişim teknolojilerinin, teknolojinin temel özelliklerini taşımakla birlikte; kendine özgü ve toplumsal yaşam üzerinde daha belirgin örüntülere sahip olduğunu da unutmamak gerekmektedir. Ortaya çıkan görüngü, yeni iletişim teknolojilerinin uygun altyapı ve teknik donanım olduğu takdirde; eskiye oranla görece düşük maliyetle, zaman ve mekan engeline takılmaksızın, herkes tarafından ulaşılabileceği gerçeğine işaret etmektedir. Buna göre pozitivist kuram çerçevesinde ele alındığında, yeni iletişim 
teknolojilerinin insan hayatını kökten değiştiren ve oldukça kolaylaştıran pek çok özelliğinden söz etmek mümkündür.

Everett M. Rogers'a (1986: 4-5) göre yeni iletişim teknolojilerinin; karş1lıklı etkileşim, kitlesizleştirme ve eşzamansızlık olmak üzere başlıca üç özelliği vardır. $\mathrm{Bu}$ özelliklerden karşılıklı etkileşim, kaynak ve alıcı arasındaki çift yönlü iletişim sürecine olanak tanımakta ve yeni iletişim teknolojilerini, kitle iletişimindeki tek yönlü işleyişten farklılaştırmaktadır. Karşılıklı etkileşimde hedef kitle olarak tanımlanan bireyler, iletişim sürecinde artık pasif değil; aktif özneler haline gelmekte ve yeni iletişim teknolojilerinin sunduğu etkileşim olanağı ile kendi istekleri doğrultusunda bilgi ve mesaj içeriğini oluşturup yönlendirebilmektedirler. Kitlesizleştirme özelliği ile büyük kullanıcı kitlelerine gönderilen mesajların, bu kitleler içerisinde yer alan bireylere yönelik özelleştirilmesi ifade edilmektedir (Geray, 1994: 7). Yeni iletişim teknolojilerinin kitlesizleştirme özelliği, kitle iletişimi çerçevesinde bireylere gönderilen özel mesajlar ile bankacılık ve alışveriş gibi bireysel işlemlere yardımcı olan birçok alanda bilgi aktarılmasını sağlamakta ve bireysel yaşamı düzenleyen bu gibi alanlarda önemli hatırlatmalarda bulunarak hayatı kolaylaştırmaktadır. Yeni iletişim teknolojilerinin eşzamansız olabilme özelliği ise, mesajların kaynak ve alıcı arasında karşılıklı olarak ve anında gönderilmesi zorunluluğunu ortadan kaldırmaktadır. Böylece dijital mesaj gönderiminin ve alımının herhangi bir kayba ya da bozulmaya uğramadan, bireyler için en uygun zamanda gerçekleştirilmesi ve iletişim sürecinin işlevsellik kazanması mümkün olmaktadır.

İletişim alanındaki gelişmeler, her şeyden önce teknolojiye moleküler bir yapı kazandırmakta ve nanoteknolojinin gelişimi, yeni teknoloji araçlarının hafifleyip küçülmesini beraberinde getirirken, topluma sunulan enformasyon ve bilgi akışının hacminin büyümesine yol açmaktadır. Öyle ki, yeni iletişim teknolojilerinin özelliklerinin gün geçtikçe artıp gelişmesi ile birlikte, enformasyon ve bilginin erişilebilirliği de artmaktadır. Ploman'a (1990: 136-137) göre yeni iletişim teknolojileri; bilginin üretilmesi, depolanması, işlenmesi ve aktarılması gibi insan hayatına doğrudan etki eden çok sayıda özellik ile karakterize edilmektedir. Bu özellikler ise, yeni iletişim teknolojilerinin işlevselliğini arttırmakta ve ucuzlayıp 
erişiminin kolaylaşmasını sağlamaktadır. Böylece bu teknolojilerin toplumsal yaşam üzerindeki belirleyici etkisi de artmaktadır.

Yeni iletişim teknolojileri, yaşamın sosyo-kültürel boyutunu da yeniden yapılandırmaktadır. Teknolojik gelişim düzeyi insanları, toplumları ve kültürleri birbirlerine yaklaştırmış; farklı özelliklere sahip kültürlerin ve toplumların birbirleri ile etkileşime girmesi, toplumsal değişim hareketlerine hız kazandırmıştır (Özçağlayan, 1998: 4). Bununla birlikte iletişim teknolojilerindeki gelişmeler; savunma sanayi, ulaştırma, lojistik, meteoroloji, jeoloji, tıp, genetik ve moleküler biyoloji başta olmak üzere, toplumsal yaşama doğrudan ve dolaylı nüfuz eden birçok alandaki yenilik ve gelişmelerin de öncülüğünü yapmaktadır. Özellikle bilgisayar ve iletişim teknolojilerindeki dinamik gelişmeler, "üretim için her türlü bilgi akışını hızlandırıp kolaylaştırdığı gibi, zaman ve mekân konusunda sağladığı avantajlarla, üretimde etkinliği ve verimliliği arttırmıştır” (Erkan, 1998: 53). Bu teknolojilerin gündelik yaşam pratiklerine entegre olması, bir yandan insan hayatını gün geçtikçe kolaylaştırıp yaşam kalitesinin yükselmesine doğrudan etki etmekte; diğer yandan da, bu teknolojilere yönelik yeni soru ve sorunları tanımlayarak gün 1şığına çıkarmaktadır.

Daha önce de belirtildiği gibi yeni iletişim teknolojileri; bireyleri, devletleri ve iletişimi, kısaca tüm yaşam koşullarını değiştirip elektronikleştirmektedir. İnsan hayatını kolaylaştıran ve birçok açıdan dönüştürüp değiştiren mikroişlemciler, fiber optik kablolar, kişisel bilgisayarlar, yüzey bilgisayarları ve yeni nesil arayüzler, içerik bilinçli ağ teknolojileri, anlamsal ağ teknolojileri, hacimsiz zeka, yapay zeka/sensör/robot teknolojileri, nesnelerin interneti ve büyük veri ile bulut bilişim gibi en yeni teknolojik gelişmeler, daha önce kas gücü ve yoğun emek ile yapılan işlerin yerini almaya başlamış ve hızla almaya da devam etmektedir. Bu dönüşümün en somut örneklerini dijitalleşme kapsamındaki bireyler ve devletlerin yanı sıra iş ve ticaret uygulamalarında da görmek mümkündür. Bu bağlamda gelişmiş ülkelerin,

\footnotetext{
- bkz: TÜBITAK, Bilim ve Teknoloji Yüksek Kurulu (BTYK) 29. Toplantısl Kararlarl, https://www.tubitak.gov.tr/sites/default/files/2016_101.pdf, Yayımlanma Tarihi: Şubat 2016, Erişim Tarihi: 28.10.2016 ve TÜBITAK ARDEB-1003 Öncelikli Alanlar Ar-Ge Projeleri Destekleme Programı, 2015-2018 Planlanan Çağrlar Kataloğu, Ankara Teknoloji Transfer Ofisi (TTO), http://www.ankaratto.com/wp-content/uploads/2015/05/1003katalog.pdf, Yayımlanma Tarihi: Mayıs 2015, Erişim Tarihi: 28.10.2016.
} 
Bilgi Toplumu çerçevesinde bilgi devrimini olanca hızıyla yaşarken, henüz sanayileşmesini tam anlamıyla tamamlayamamış gelişmekte olan ve azgelişmiş ülkeler açısından yapılacaklar listesinin oldukça kabarık olduğu gözlenmektedir. $\mathrm{Bu}$ açıdan ele alındığında, yeni iletişim teknolojilerinin toplumsal yaşama işlevsel bir şekilde uyarlanabilmesi; teknolojik altyapının iyileştirilmesine ve hukukî, politik ve sosyo-kültürel zeminde düzenlemelerin gerçekleştirilmesine bağlı görülmektedir.

Küresel dönüşümü yakalamak için dijital örüntülerden oluşması zorunlu hale gelen yaşam pratikleri, daha önce ütopik romanlar dışında hayal edilemez somut sonuçlarıyla karşımızda durmakta ve bu yeni elektronik yaşam, tüm gerçekliğiyle hayatımıza nüfuz etmektedir. Söz konusu yeni gerçeklikle başa çıkabilmek ise, her şeyden önce yarının teknolojisine cevap verebilen hukuki altyapının ve yasal düzenlemelerin oluşturulmasına ve bu mekanizmalara işlevsellik kazandırılmasına bağlıdır. Ancak insanoğlunun sadece teknik ve hukukî boyutlu bir varlık olmadığı göz önüne alındığında, psikolojik ve sosyo-kültürel ihtiyaçlarını da kapsayacak yasal düzenlemelerin yürürlüğe konmasının çok da kolay olmadığı anlaşılmaktadır.

Bununla birlikte, yeni iletişim teknolojilerinin toplumlar ve ülkeler, hatta dünyanın Kuzey ve Güney Yarımküresi arasındaki kutuplaşmayı daha da arttırıp dijital uçurumu (digital divide) derinleştireceği yönündeki görüşler, halen yoğun bir şekilde tartışılmaya devam etmekte ve bu teknolojilerin etik, güvenlik ve mahremiyete yönelik etkisi birçok eleştirel çalışmada ele alınmaktadır. Hayatın her alanının elektronikleştiği dijital çağda yeni iletişim teknolojilerinin birbirinden ayrı düşünülemeyen bu üç bileşeni içeren konularda gösterdiği duyarlılık; bireylerin, işletmelerin ve devletlerin dijital dünyada sağlıklı bir şekilde temsil edilmesinde ve varl1k göstermesinde önemli bir role sahiptir. Ancak yasal düzenlemeleri belirlemek her zaman teoride göründüğü kadar basit olmamaktadır. 'Kişisel hak ve özgürlükler nerede başlar ve biter' gibi cevaplaması pek çok açıdan oldukça zor olan bir sorunun birey, işletme ve devlet perspektifinden farklı uygulama boyutları bulunmaktadır. $\mathrm{Bu}$ sorunun kavramsallaştırılarak ortak akıl çerçevesinde çözülmeye çalışılması, yeni iletişim teknolojilerinin kabul edilmesinde ve toplumsal yaşam paradigmalarına uyarlanmasında önem taşımakta ve zorunlu görülmektedir. Daha önce de belirtildiği gibi, yeni iletişim teknolojilerini mahremiyet bağlamında sorgulamaya geçmeden 
önce, çalışmanın amacı ve mahremiyet kavramının doğası gereği, etik olgusunu çalışmanın sınırları dahilinde ele almak, çalışmaya ana izlek doğrultusunda bütünsel bir perspektif kazandiracaktır.

\section{Yeni İletişim Teknolojileri ve Etik Boyut}

Ahlak ve etik kavramlarının ilk çağ düşünürlerinden bu yana araştırıldığını ve her çă̆ın, kendi dinamik özelliklerine göre, bu iki kavramı farklı yönlerinden ele aldığı görülmektedir. Yunanca ethos sözcüğünden türemiş olan etik, en genel anlamıyla; “insanın dünyadaki varoluş amacına odaklanarak insan doğası için iyi olanla kötü olanın neler olduğunu belirginleştiren; insanın gerek kişisel gerekse toplumsal yaşamda karşılaştığı sorunları bütün yönleri ile enine boyuna ele alıp, çözüm önerileri getiren felsefi disiplindir" (Ulaş vd., 2002: 501). Etik, evrensel normları dikte ettirmekte ve ahlak felsefesi alanını tanımlamaktadır. Etik, bir kişsinin bir eylemde bulunmaya karar vermesinden ziyade, neye karar verdiği ve verdiği kararla gerçekte ne yaptığı ile ilgilenir (Kuçuradi, 2006: 65). Bu noktada benzer şekilde Pieper de (1999: 29) etiğin konusunun; her türlü insanî faaliyetler olmadığını, insan faaliyetlerinde ahlakî olmayı önceleyen eylemler olduğunu vurgulamaktadır. O halde ahlakın teoriye dökülmüş hali olan ve bu nedenle ahlaka göre kapsamı daha geniş tutulan etik kavramı, ahlakın ne olduğunu tartışan ve insanın ahlaklı tanımlanabilmesi için nasıl eylemesi gerektiği üzerine kafa yoran felsefi bir disiplin, bir bilim dalı olarak karşımıza çıkmaktadır. "Ahlak görüşü, etik yaşamın içinde dahi sürekli bir imkan olarak bulunur; onun tarafından içerilir, bertaraf edilmez" (Benhabib, 2005: 113). Buna göre ahlak, bireysel ve toplumsal düzeyde ele alınan olguları ifade ederken; etik, tüm ahlaksal fenomenleri sınıflayarak gerçek anlamda evrensel iyiye ulaşmak için neler yapılması gerektiğini sorgulayan felsefe disiplini olarak belirmektedir.

Toplumsal hayatın giderek karmaşık bir yapı kazanması ve her geçen gün yeni meslek çeşitlerinin doğması, eski ve yeni tüm meslekler için birtakım düzenlemeler yapılmasını zorunlu kılmakta ve böylece her meslek için etik ilkelerin oluşturulup düzenlenmesi gündeme gelmektedir. Toplumsal yaşamı dizginlemeyi ve çeşitli kurallara bağlayıp daha anlaşılır kılmayı amaçlayan etik düzenlemeler, yeni iletişim teknolojileri çerçevesinde de yoğunlaşmaktadır. Çünkü dijital platformdaki 
bilişim suçları ile mücadelede ulusal veya uluslarüstü kurumlar tarafından alınan olağanüstü önlemler, çoğu zaman bilişim suçlarının önüne geçememektedir. $\mathrm{Bu}$ doğrultuda, bilişim etiğini kapsayan davranış kurallarının, sanal dünyada taraf olan bireylerce özümsenmeden, bu konuda pratikte başarılı ve kalıcı bir sonucun alınması mümkün görünmemektedir. Birçok mesleğin etik ilkelerinin, uzun bir zaman içerisinde ve belirli aşamalardan geçip olgunlaşmasına rağmen; teknoloji alanına dair etik ilkelerin, toplumsal arenada karşımıza çıkan değişim ivmesine koşut bir gelişim süreci ile varlık kazandığı söylenebilmektedir. Yeni iletişim teknolojileri bağlamında genel kabul gören etik ilkeler, şu şekilde ifade edilebilmektedir (Türkiye Bilişim Derneği, 2007: 18):

- Toplumun ve insanlığın daha iyi şartlar altında yaşamasına katkıda bulunmak,

- Zarar verici davranışlardan kaçınmak,

- Telif ve patent haklarını da içeren mali ve manevi haklara saygı göstermek,

- Dürüst ve güvenilir olmak,

- Sadece izin verildiği sürece bilgileri otomatik işleme tabi tutulmuş kaynaklara erişimin sağlanması,

- Gizlilik ilkesine saygı gösterilmesi.

Burada da görülebileceği üzere, bilişim etiğinin ilkeleri açık bir şekilde belirlenen yazılı kurallardan oluşmakta ve evrensel kabul gören kavramlara dayanmaktadır. Bilişim alanındaki bu etik ilkeler, özü itibariyle iletişim etiğinden beslenmekte ve iletişim etiği ise Benhabib'e (1999: 87) göre, sorun çözmenin iş birliğine ve birliğe dayalı metotlarını teşvik etmenin yanı sıra çatışmaları çözüme kavuşturmanın şiddete dayalı olmayan stratejilerini öngörmektedir. Buradan hareketle, Türkiye Bilişim Vakfı'nın (TBV) belirlediği bilişim etiğine yönelik meslek ilkelerinin, sözü edilen kazanımların içselleştirilmesinde önemli paya sahip olduğu vurgulanabilmektedir. Türkiye Bilişim Vakfı, hazırladığı Bilişim Mesleği Ahlak Illkeleri Belgesi'nde; bir bilişimcinin, mesleğinin gereklerini yerine getirirken dikkat etmesi gerekenleri Temel Illkeler başlı̆̆ı altında şu şekilde belirtmektedir (Türkiye Bilişim Vakfı, 2015):

- Toplumun ve bireylerin güvenliğini, sağlı̆̆ını ve esenliğini gözetir. 
- Adil, dürüst ve güvenilir olup tüm insanlara karşı hiçbir ayrım gözetmeksizin eşit davranir.

- İnsanların özel yaşamına, saygınlığına ve iyelik haklarına saygı gösterir.

İnternet dünyasında denetim ve düzenleme gücüne sahip aktörlerin güçlerini kötüye kullanmamaları, her şeyden önce etik konusunun vizyoner açılımlar gerçekleştirerek dijital dünyada güvenliğin sağlanması ve bu alanda önemli kazanımlar elde edilmesi noktasında büyük bir rol oynamaktadır. Buna göre dijital dünyada etik, başkalarının kişisel haklarına duyarlı ve saygılı davranarak kişisel hak ve çıkarlarına zarar vermemeyi ifade etmektedir. "Bir başkasının hak ve çıkarlarına zarar verici nitelikten kasıt; siber zorbalık, sanal ortamda hakaret ve benzeri olguların yaşanmasıdır" (Gündüz ve Engin, 2016: 52). Bu bağlamda uluslararası arenada Küresel Internet Projesi ve Elektronik Mahremiyet Enformasyon Merkezi gibi birliklerin iş birliği içerisinde yeni iletişim teknolojilerine yönelik hukukî çerçeve ve etik konularında faaliyette bulunmaları, etiğin dijital dünyadaki rolünün kavranmasında önemli bir itki olarak değerlendirilmektedir. Bunlara ek olarak 1985 yılında kurulan Bilgisayar Etik Enstitüsü (Computer Ethics Institute) tarafindan geliştirilen ve dünya çapında kabul gören aşağıda sıralanmış temel ilkeler, etik olgusunun kapsayıcılığının arttırılıp dijital platformlara uyarlandığını göstermektedir (İşman, 2016: 78):

- Bilgisayarı başka insanlara zarar vermek için kullanmamak,

- Başka insanların bilgisayar çalışmalarına karışmamak,

- Başka insanların dosyalarını karıştırmamak,

- Bilgisayarı hırsızlık yapmak için kullanmamak,

- Bilgisayarı yalan bilgiyi yaymak için kullanmamak,

- Bedeli ödenmemiş yazılımı kopyalamamak ya da kullanmamak,

- Başka insanların bilgisayar kaynaklarını izin almadan kullanmamak,

- Başka insanların entelektüel bilgilerini kendine mal etmemek,

- Yazılan bir programın ya da tasarlanan bir sistemin sosyal hayata etkilerini düşünmek,

bkz: http://computerethicsinstitute.org/images/ TheTenCommandmentsOfComputerEthics.pdf, The Ten Commandments of Computer Ethics, Erişim Tarihi: 25.01.2017. 
- Bilgisayarı, diğer insanlara saygı duyarak ve onları dikkate alacak şekilde kullanmak.

Yeni iletişim teknolojilerinin herkes tarafından içselleştirilip güvenle kullanılabilmesi, bu alanda sözü edilen temel etik normların ve standartların özümsenmesine ve her ne olursa olsun belirlenen ilkelerden taviz verilmemesine bağlıdır. Ancak yine bu teknolojilerin olanakları doğrultusunda yararlanılan görüntüyle oynama tekniklerinin bir sonucu olan görüntü manipülasyonu (Pavlik, 2001: 86) çeşitli yanılsamaların ortaya çıkmasında büyük bir rol oynamakta ve bu yönüyle yeni iletişim teknolojilerinin etik bağlamında sorgulandığı temel konuyu oluşturmaktadır. Günümüzde yeni iletişim teknolojileri aracılığıyla her türlü fotoğraf ya da video görüntüsü kolayca manipüle edilebilmekte ve bu görüntüler kişi, zaman ve mekan bütünlüğünü bozacak birçok şekilde kurgulanıp aktarılabilmektedir. Teknolojinin dijitalleşmesi sonucu ortaya çıkan dijital manipülasyon önemli bir etik sorundur ve özellikle siyaset, miting, savaş ve protesto eylemlerinde kullanılması ciddi sorunlar yaratabilmektedir (Korkmaz, 2014: 28). Bu durum, kaçınılmaz olarak yoğun bir dezenformasyon akışına yol açmaktadır. Örneğin; seçim dönemlerinde siyasi partilerin düzenlediği mitinglere, çok sayıda kişinin katıldığını iddia edebilmek için miting alanındaki görüntülerin 'klonlama' tekniği kullanılarak kolayca çoğaltılması, yeni iletişim teknolojileri ile mümkün hale gelmiştir (Geray ve Aydoğan, 2009: 312). Böylece yeni iletişim teknolojileri uzamında şekillenen toplumsal yaşamda gerçeklik algısı, bir yanılsama olarak karşımıza çıkmakta ve bu durumun kendisi başlı başına etik bir sorun niteliği taşımaktadır.

Bu noktada Baudrillard'a (2014: 41) göre yeni iletişim teknolojileri aracılığıyla, gerçekliğin istenen şekilde ve sürekli üretimi ile gerçek olanın yerini, taklit edilen sahte gerçekliğin (hipergerçeklik) alması söz konusu olmaktadır. Bu süreç ise, ortaya çıkan simülasyonlar içerisinde giderek gerçeklikten uzaklaşmaya ve gerçek olandan kopmaya yol açmaktadır. "Yapaylık ve simülasyonlar, gerçekliğin olanaklarını sonsuz biçimde çoğaltmalarına karşın asla gerçeklik değildir”" (Sartori, 2004: 24). Buna göre yeni iletişim teknolojilerinin gelişimi ve yaygın kullanımı sonucu, gerçek ve sahte arasındaki sınır giderek ortadan kaybolmakta ve bu durum, toplumsal yaşam içerisinde algıların bozulmasına neden olarak yanılsamaya yol açmaktadır. "Dış dünyayı algılama biçimimiz; yeni iletişim teknolojileri ile birlikte 
dönüşüme uğrayarak, gerçeklik kavramının yeniden tanımlanmasına neden olmaktadır (Robins, 2013: 35). Dolayısıyla yeni iletişim teknolojilerinin doğası ve özellikle sahte gerçeklik algısı yaratmak için hakim ideoloji ya da aktörler tarafindan tehlikeli bir biçimde kullanılması (ya da bu potansiyelin varlığı), bu teknolojilere yöneltilen etik suçlamalara zemin hazırlamaktadır. Yeni iletişim teknolojileri bağlamında ulusal ve uluslararası çapta belirlenen diğer etik sorunlar şu şekilde siralanabilmektedir (Binark ve Bayraktutan, 2013: 39):

Özel yaşamın gizliliği, telif/patent hakları, içeriğin asıl kaynağının gösterilmemesi, üretilen içeriklerin olgunlaşmadan ve doğruluğunun teyit edilmeden yayılması, kişisel verilerin güvenliğinin sağlanamaması, veri madenciliği, dijital gözetim, haber ve ticari enformasyonun sınırlarının belirsizleşmesi, yeni medya ortamındaki yoğun reklam içeriği, yanıltıcı etiketleme ve başlıklandırılma, nefret söylemi ve bireyin yeni medya ortamında sadece tüketici olarak konumlandırılması.

Yeni iletişim teknolojilerinin sözü edilen etik sorunlar karşısında güçlendirilmesi, ancak bu tartışmalı alanlarda etik konusuna gereken önemin verilmesi ile mümkün olacaktır. Daha önce de vurgulandığı gibi, yeni iletişim teknolojileri toplumsal yaşamın her alanını dönüştürmektedir. Etik kavramı da bu dijital dönüşüme koşut olarak değişmekte ve yeniden üretilmektedir. Dolayısıyla yeni iletişim teknolojilerini sorgularken; çalışma kapsamında nihai durak olan mahremiyetten önce, bu sorgulamanın iki temel uğrak noktası olan etik ve güvenlik konusundaki açmazların bütünsel bir şekilde ele alınması, bir gereklilik olarak göze çarpmaktadır.

\section{Yeni İletişim Teknolojilerinde Güvenlik ve Mahremiyet Sorunu}

Bilginin zaman ve mekan bariyerine takılmadan sınırsız paylaşımı ilkesi, bir ucuyla bilgi ve iletişim özgürlüğü kavramına dokunurken, diğer bir ucuyla da özel hayatın gizliliği ve kutsallığı kapsamında güvenlik ve mahremiyet kavramlarıyla çatışma yaratmaktadır. Bilgi güvenliği, özel hayat ve mahrem alan kavramları ile ilgili olarak özellikle 11 Eylül olayları sonrasında bir çeşit toplumsal paranoyanın ortaya çıktığı ileri sürülebilmektedir. Ortaya çıkan paranoya toplumları çerçevesinde, ülkelerin terörist saldırıları önlemek ve ulusal güvenliği sağlamak amacıyla geliştirdikleri politikalar, sürekli bir olağanüstü hal durumunun giderek 
kanıksanmasına yol açmakta ve dünyanın önde gelen gelişmiş ülkeleri bu durumu yasal düzenlemelerle de meşrulaştırmaktadırlar. Uçkan (2008); anti-terör yasaları ile devleti korumak için bireysel hak ve özgürlüklere kısıtlama getirilmesinin tehlikelerine vurgu yaparak özellikle kişisel ya da kurumsal mahremiyet, kişisel verilerin korunması, sansür, bask1, izleme, 'terör' tanımı vb. birçok konunun, bu bağlamda önemli bir kaygı kaynağı olarak karşımıza çıktığına işaret etmektedir. $\mathrm{Bu}$ kavramların her biri, dijital dünyada güvenlik ve mahremiyete yönelik çerçevede temel risklerin referans kaynağını oluşturmakla birlikte; her biri, tek başına bir araştırma konusu olabilecek niteliktedir. Ancak daha önce de vurgulandığı gibi, çalışmanın amacı bu olgu ve kavramları tek tek açıklamak değil; yeni iletişim teknolojileri bağlamında ele alınan bu konulardaki mevcut ve potansiyel sorunlara odaklanmaktır.

Bilgi Teknolojileri ve İletişim Kurumu (BTK) tarafından 2009 yılında dijital dünyada güvenliği tehdit eden risklere' yönelik ilk kez gerçekleştirilen 'Siber Güvenliğin Sağlanması' konulu kapsamlı çalışmadan sonra, T.C. Ulaştırma, Denizcilik ve Haberleşme Bakanlığı'nın 2016-2019 vizyonundan hareketle 'Ulusal Siber Güvenlik Stratejisi’nde belirlenen ve çözüm aranan güvenlik açıkları şu şekilde özetlenebilmektedir:

Kamu sektöründe ve özel sektörde faaliyet gösteren her türlü kurum ve kuruluşta sunulan hizmetleri engelleyen saldırılar, bilgi çalmaya yönelik kötücül yazılımlar (ajan yazılımlar, virüsler, solucanlar, Truva atı ve klavye kaydedici vb.), yemleme (oltalama) yöntemi ile dolandırıcılık, istenmeyen elektronik posta gönderimi (Spam), haberleşme araçlarını dinleme ve bu araçlara sızma, kişisel ve kurumsal verilerin izinsiz sızdırılması, propaganda amaçlı bilgisayar korsanlığı (hacktivizm), teknolojik casusluklar, istihbarat amaçlı takip ve gözetleme, özel veya ticari değere sahip bilgilerin ifşa olması, değiştirilmesi ya da yok edilmesi, kimlik hırsızlığı ile sahte işlem yapılması, kişisel gizlilik ve mahremiyet bağlamında korunması gereken özel bilgilerin ve cihazların ele geçirilmesi, değiştirilmesi veya yok edilmesi.

\footnotetext{
- bkz: Bilgi Teknolojileri ve İletişim Kurumu (BTK), Siber Güvenliğin Sağlanması: Türkiye'deki Mevcut Durum ve Alınmasi Gereken Tedbirler, (Hazırlayanlar: Mustafa Ünver vd.), https://btk.gov.tr/File/?path=ROOT\%2F1\%2FDocuments\%2FSayfalar\%2FSiberGuvenlik\%2Fsg.pdf, Yayımlanma Tarihi: Mayıs 2009, Erişim Tarihi: 25.01.2017.

bkz: T.C. Ulaştırma, Denizcilik ve Haberleşme Bakanlı̆̆l, 2016-2019 Ulusal Siber Güvenlik Stratejisi, http://www.udhb.gov.tr/doc/siberg/2016-2019guvenlik.pdf, Yayımlanma Tarihi: Kasım 2016, Erişim Tarihi: 25.01.2017.
} 
Burada da görülebileceği gibi, yeni iletişim teknolojilerinde gizlilik ve güvenliği tehdit eden riskler ve bu riskleri ortadan kaldırmak için gerçekleştirilmesi gereken düzenlemeler, mahremiyet konusundan ayrı düşünülememektedir. Dijital yaşamın temelini oluşturan yeni iletişim teknolojileri, yeterli önlem alınmadığı takdirde; gizliliğin, güvenliğin ve mahremiyetin ortadan kalkmasına ve küresel ağ üzerinden gönderilen bilgilere üçüncü kişilerce erişilmesine; hatta bunların, söz konusu kişilerin amaçları doğrultusunda her an değiştirilmesine açık, tehlikeli bir yap1 sergilemektedir. Özellikle yeni iletişim teknolojilerinin her türlü veri gözetimini mümkün kılan ve kolaylaştıran doğası, bu gibi sorunları ortaya çıkarıp beslemektedir. “Tıpkı geleneksel sızma yollarında olduğu gibi, modern gözetleme ve dinleme aygıtlarıyla özel yaşam alanına yönelik müdahaleler de özel amaçlarla yapılabildiği gibi resmi amaçlarla da yapılabilmektedir" (Özsunay, 1978: 131). 2010 yılında Amerika Birleşik Devletleri (ABD) Dış İşleri Bakanlığı'nın 1960'lardan itibaren gerçekleştirdiği gizli yazışmaların, doküman ve görüntülerin WikiLeaks internet sitesinden dünya kamuoyuna sızdırılması ile uluslararası diplomatik bir krize dönüşen olaylar zinciri, dijital güvenliğe yönelik tartışmaları alevlendiren en somut örneklerden biri olarak karşımıza çıkmaktadır.

İçinde yaşadığımız iletişim çağı, duygularımızı ve davranışlarımızı açıklamaya yönelik her türlü bilginin, her an ve her durumda izlenip saklanmasına ve bu bilgilere istenen zamanda ulaşılmasına olanak sağlamaktadır. Yeni iletişim teknolojileri kapsamında sürekli gelişen ve güncellenen mobil iletişim cihazları artık herkesin cebine sığabilecek kadar küçülmüştür ve bu teknolojiler ile popüler sosyal ağlar üzerinden dünyaya açılmak ve dünyanın her köşesinden ulaşılabilir olmak mümkündür. $\mathrm{Bu}$ durum ise, kişisel gizlilik ve mahremiyete çoğu zaman zarar verebilmektedir. Kişisel gizlilik, “insanlar hakkındaki enformasyonun nasıl işleneceğ $i$, bu verilere kimlerin erişeceği ve bu erişimin nasıl düzenleneceği hakkındaki ahlakî sorular" (Fuchs, 2014: 216) olarak ele alındığında, yeni iletişim teknolojilerinin doğası gereği kişisel gizlilik, güvenlik ve mahremiyet olguları ile çatışan bir eksende ilerlediği söylenebilmektedir.

Yeni iletişim teknolojileri kişisel mahremiyeti giderek yok etmekte; dahası, kişisel yaşantıların sürekli gözlenerek analiz edilmesini ve yorumlanmasını mümkün 
kılmaktadır. Mahremiyet, artık sabit alanları tanımlamamaktadır. Mahremiyet ve gözetim, artık akışkan bir kelimedir... İmajlar ve mesajlar, internet sistemleri aracılığıyla akar. Bu durum, iletişimin giderek daha hareketli (mobil) olduğu anlamına gelir ve hareket halindeki insanların gözetimden kaçma umutları yoktur (Castells, 1996: 376). Teknolojik gelişmelerin toplumsal hayata entegre olması aşamasında var olan hukukî altyapı ve uygulanan yasal düzenlemeler ise, bu tür konuları düzenlemede -şu an için- yetersiz ve muğlak kalmaktadır. Bu nedenle "bilgi gizliliğinin elektronik ortamda korunması, en çok endişe doğuran alanların başında gelmektedir" (Tortop, 2000: 9). Sorunun giderilmesindeki zorluklar, gizliliğin sağlanması için gerekli yasal düzenlemelerin -ironik bir şekilde- kişisel hak ve özgürlükler ile çatıştığı düşüncesinden ve inancından kaynaklanmaktadır.

$\mathrm{Bu}$ doğrultuda, mahremiyet ihlalinin doruk noktası olarak kavramsallaştırılabilen sanal gözetim konusunun, kişisel güvenlik ve mahremiyeti zedeleyen önemli risklerden birini oluşturduğu görülebilmektedir. Yeni iletişim teknolojilerinin kolaylaştırdığı ve bir bakıma herkesi küresel ağ içerisinde görünür olmaya gönüllü hale getirdiği sanal gözetim, çeşitli tehlikeleri ve riskleri de beraberinde getirmektedir. Bu bağlamda; "kişilerin sağlı̆̆ına, banka hesaplarına, dinsel inançlarına, siyasal görünüşlerine, etnik kökenlerine, cinsel yaşamlarına vb. ilişkin bilgiler çeşitli amaçlarla kullanılabilmekte... ve bireylerin mali durumlarına, sağlık sorunlarına ve sabıka kayıtlarına ilişkin bilgilere kolayca erişilebilmektedir" (Yüksel, 2003: 211). Bu noktadan hareketle, gelecekte özel hayatın ve mahremiyetin daha da daralacağı yönünde kuşkular artmakta ve gözetim toplumu tüm gerçekliğiyle karşımıza çıkmaktadır. Yeni iletişim teknolojileri aracılığıyla gözetim, biçim değiştirmekte ve kolaylaşmaktadır. Bu teknolojiler tarafından kuşatılan bireyler, güvenlik ve özgürlük arasında seçim yapmaya zorlanmakta; bireylere özgürlük vaadi sunan bu araçlar, aynı zamanda mahremiyeti kısıtlamaktadır. Dijital toplum bireyleri yeni ve öncekine göre daha farklı ve karmaşık tehlikelerle karşı karşıya kalmaktadır (Çalık ve Toker, 2016: 9). Bilgi güvenliği sağlanamayan, kişisel mahremiyete özen gösterilmeyen ve sürekli gözetimi mümkün kılan küresel ağ içerisinde, dijital suçların denetiminin ve kontrol altına alınmasının zorluğu da açıkça karşımıza çıkmaktadır. 
Hedef kitlelerle uzun soluklu iletişimi mümkün k1lan etkin veri tabanı kullanımı ve yönetimi, akıllı kartlar ile yapılan alışverişin sürekli kayıt altında tutulması veya ulusal güvenlik ekseninde sanal ortamda ziyaret edilen internet sitelerinin takip edilmesi, her şeyi izleyen, gözetleyen ve not alan bir sistemin; George Orwell'in ütopik romanı 1984'teki Big Brother-Büyük Birader kurgusunun gerçeğe dönüştüğünün ve somut bir varlık kazandığının göstergesi olarak değerlendirilebilmektedir. " $\mathrm{Bu}$ romanın günümüze yansıması, bilgisayarlar aracılığıyla toplumu daha sıkı bir denetim altına almak isteyenler olabileceği endişesidir" (Akın, 2001: 29). Çünkü gözetim konusu, her zaman iktidar ile ilintilendirilmiştir. "Enformasyon toplumu olarak adlandırılan günümüzdeyse, gözetim pratikleri -yine iktidar ve egemenlik ilişkileri bağlamında- tümüyle yüksek teknolojinin imkanlarına dayalı bir karakteristiğe bürünmüştür” (Dolgun, 2008: 37). Neredeyse her yerde gerçekleştirilen her eylemin kayıt altına alındığı bir toplum yapısı -ki Castells (1996) bu yapıyı ‘A $\breve{g}$ Toplumu’ kavramı ile açıklamaktadır- yeni iletişim teknolojilerine dair endişeleri de beslemektedir. $\mathrm{Bu}$ endişe, David Lyon (2006: 286) tarafından da yeni iletişim teknolojilerinin ortaya çıkardı̆̆ı 'gözetim toplumu' paradigması üzerinden şu şekilde aktarılmaktadır:

Havaalanlarında gözümüzü kırpmadan tarayıcıların okuması için pasaportlarımızı veririz; büyük bulvarlardaki banka makinelerini kişisel kimlik bilgileri taşıyan plastik kartlarla besleriz; bir cihaz satın aldığımızda garanti belgelerini doldururuz; online değişimlerde anahtar gizli verileri gireriz; şehir içinde ya da otoyolda geçiş parası algılayıcılarının içinden geçerek araba kullanırız; cep telefonu konuşmaları yaparız ya da ofislere ve laboratuvarlara girmek için barkodlanmış anahtarlar kullanırız.

Bireylerin en temel psikolojik ihtiyaçları arasında yer alan güvenlik ve mahremiyet olgularına her çağda rastlanmakla birlikte, bu kavramların günümüzdeki anlamıyla modernleşme sürecinde önem kazanmaya başladı̆̆ı söylenebilmektedir. Mahremiyet hakkı, kişilerin kamusal hayatta hangi sıklıkla yer alacakları konusunda karar verme yetisine sahip olduklarını belirtmekte ve bireylere psikolojik bir rahatlık sağlamaktadır. "Mahrem yaşamın en hassasiyetle üzerinde durulan koruma alanlarından biri ise haberleşme mahremiyetidir ve günümüzde vazgeçilmez kişi haklarından biri olarak kabul görür” (Tanılır, 2002: 44). Ancak internetin yaygın kullanımı, temel kişisel hak ve özgürlükler bağlamında çoğu zaman eleştirileri de 
beraberinde getirmektedir. Her gün kullandığımız elektronik veri tabanları, arama motorları ve hatta günlük elektronik postalar bile, kişisel mahremiyetin ihlal edildiği sancılı noktalar olarak karşımıza çıkabilmektedir. Atabek'e (2006: 3) göre; e-posta adresleri ile iletilen içerik kadar, bizzat bu adreslerin kendileri de bir mahremiyet konusudur. Tıpkı kamusal metinlerde yer alan telefon numaralarının herkese açık olmaması gerektiği gibi, e-posta adreslerinin de herkesin erişimine açık olmaması gerekmektedir. Buradan hareketle gizlilik, güvenlik ve mahremiyet isteğini en basit anlamıyla, toplumsal yaşam pratiklerine yönelik etik bir özlem olarak değerlendirmek mümkündür.

Yeni iletişim teknolojileri daha önce de vurgulandığı gibi, doğası gereği pek çok alanda hayatımızı kolaylaştıran akıllı uygulamalar olarak karşımıza çıkmaktadır. Örneğin, kişisel sağlık bilgilerinin özel akıllı kartlar aracılığıyla istenilen her yere taşınabilmesi mümkün hale gelmektedir. Bu sayede herhangi bir doktorun, akıllı kartlara sahip bireylerin daha önceki sağlık durumları hakkında geniş bilgiye ulaşabilecekleri düşünülebilmektedir. Hatta sağlık hizmeti bulunmayan yerlerde, internet üzerinden tam teşekküllü sağlık kuruluşlarınca sağlık hizmeti sunulması da günümüz teknolojisi ile mümkün olabilmektedir. Anayasa ile güvence altına alınıp korunan ve bireysel mahremiyet kapsamında elde edilen kişisel sağlık verileri, yeni iletişim teknolojileri sayesinde konsültasyon amacı ile kıtalar arasında dolaşabilmekte ve bu durum, bireylere en yeni tedavi olanaklarından yararlanmaları için büyük bir şans tanımaktadır.

Ancak yazılım programlarının eksiklikleri ya da yeni iletişim teknolojilerinin açıkları gibi herhangi bir sebepten ötürü, bu çok özel ve gizli bilgilerin art niyetli kişi ve kurumların eline geçebilme düşüncesi, güvenlik ve mahremiyet konusunda tartışmalı bir alana da dikkat çekmektedir. İnsanın genetik yapısını analiz etmeye yönelik kapsamlı bir çalışma olan Insan Genom Projesi* ile hücrenin genetik haritasına ulaşıldığı ileri sürülmekte ve böylece gelecekte genetik yapıdaki tüm bilgilerin bir çip içerisine yerleştirilerek kayıt altına alınıp saklanmasının uzak bir ihtimal olmadığı öngörülmektedir. Genetik bilgilerin kopyalanabilirliği, organ

\footnotetext{
* Robert J. Robbins, "Challenges in the Human Genome Project", IEEE Engineering in Biology and Medicine, 11 (1), (March) 1992, ss. 25-34.
} 
mafyası, sigorta şirketlerinin çıkarları gibi pek çok olumsuz durum; bireyleri, yeni iletişim teknolojilerine karşı kişisel güvenlik ve mahremiyet noktasında tedirginliğe sürüklemektedir. Bu konuda; genetik bilginin sahipliği kadar, ne amaçla kullanılacağı ve genetik müdahalenin kriterlerinin nasıl saptanacağı gibi temel sorular ve çözüm bekleyen sorunlar karşımıza çıkmaktadır. Yeni iletişim teknolojileri, bu gibi potansiyellerin varlığından dolayı, çoğu zaman özel hayatın gizliliği ilkesi ile ters düşmekte ve gözetim toplumu paranoyası içinde yeni etik, güvenlik ve mahremiyet sorunlarını gün ışı̆̆ına çıkarmaktadır.

Yeni iletişim teknolojileri ile internet üzerinden alışveriş yapmak da giderek yaygınlaşmaktadır. Sanal ortamda gezerek fiyatları ve malların özelliklerini karşılaştırmak, para yerine kredi kartı ile ödeme yapıp alınanların adrese teslim edilmesini istemek; kısaca dijital ortamda nüfus cüzdanı yerine kredi kartına benzeyen kişisel bilgileri depolayan akıllı kartlar ile fiziksel olarak görünmeden alışveriş yapmak daha fazla mümkün olmaktadır. Üstelik bu kartlarla kimliği onaylamak için, özel yazılım teknolojilerinin kullanılması ile sahteciliğin önüne de geçilebilmekte, ancak bu durum diğer etik ve mahrem alan ihlallerinin sorgulanmasını da beraberinde getirmektedir. Bu kartlar aracılığı ile atılan her adımın izlenmesi, takip edilmesi, kayıt altına alınması ve depolanıp saklanması mümkün olmaktadır. "Tüm bu süreçlerin geneline baktığımızda dijitalleşme, verimliliği arttıran bir özellik taşısa da dijitalleşmenin veri üretimine, veri analizinin de mahremiyet konusunda çeşitli sorunlara sebep olma potansiyeli bulunmaktadır" (Şener ve Kuş, 2015: 77). Etik, kişisel güvenlik ve mahremiyet alanına dair bu gibi sorular ve sorunlar, yeni iletişim teknolojilerine yönelik hukukî, politik ve sosyokültürel düzenlemeler kapsamında çözüm beklemektedir.

Görüldüğü gibi, yeni iletişim teknolojilerinin sorgulanmasında temel referans noktaları olarak etik, güvenlik ve mahremiyet konuları, birbiri içine geçmiş bir zincirin kopmaz halkaları niteliğinde karşımıza çıkmaktadır. Bu nedenle yeni iletişim teknolojileri için yapılacak çok boyutlu düzenlemelerin; bilişim etiğine, kişisel bilgilerin gizliliğine ve özel hayatın mahremiyetine zarar vermeyecek bir şekilde, aksine; etik, güvenlik ve mahremiyet kesişiminde ortaya çıkan açmazları gidermeye yönelik işlevsel prosedürler çerçevesinde ele alınması gerekmektedir. Bu vizyondan 
hareket eden bir yaklaşım, elektronikleşen bireyi ve elektronikleşen yaşamı birbirine entegre ederek yeniden yapılandıracak ve yeni iletişim teknolojilerinin yaşam kalitesini arttıracak şekilde topluma nüfuz etmesine yardımcı olacaktır.

\section{SONUÇ}

Teknolojinin her çağda kendine özgü yasaları ile var olduğu ve insan hayatını doğrudan etkilediği bilinmektedir. Tıpkı çalışmanın en başında yer verilen Budist özdeyişinde vurgulandığı gibi; teknolojinin, kendi başına yararlı ya da zararlı gibi bir sıfata sahip olmamasına rağmen; kimlerin elinde ve ne amaçla kullanıldığı bilgisi, insanlığın geleceği açısından her zaman önemini korumaktadır. Bu nedenle teknolojik yenilikler, insanların düzenli bir yaşam sürmeleri için oluşturulmuş ve yasal çerçevesi belirlenmiş hukukî, politik ve sosyo-kültürel boyutlu düzenlemeler ile birlikte anılmaktadır. Ancak, teknolojinin günümüzde ulaştığı doruk noktası ve her geçen gün daha da ivme kazanması, bu düzenlemeleri teknoloji karşısında yetersiz bırakmaktadır. $\mathrm{Bu}$ durum ise, yeni iletişim teknolojilerine şüphe ve güvensizlik ekseninde yaklaşılmasını beraberinde getirmektedir. Oysa teknolojinin, kendini yaratan ve besleyen dinamik koşullarla birlikte ele alınıp yapılandırılması gerekmektedir. Bu konuda, gerçekleştirilmesi gereken düzenlemelere dair doğru soruları sormak ve sorunların çerçevesini doğru çizmek büyük önem taşımaktadır.

Özellikle az gelişmiş ve gelişmekte olan ülkeler odaklı düşünüldüğünde, bu ülkelerin tam anlamıyla sanayileşmelerini tamamlamadan, bir üst aşama olan bilgi toplumu ile karşı karşıya kaldıkları söylenebilmektedir. Bu durum, söz konusu ülkeler açısından bir dezavantaj olarak değerlendirilse de bilgi toplumunun tüm dünyada henüz emekleme aşamasında olduğu ve gelişmiş ülkelerde bile çeşitli toplumsal sancılara yol açtığı düşünüldüğünde; bu ülkelerin de tarihsel dönüşümü yakalamak için büyük bir fırsata sahip olduklarını söylemek mümkündür. İster gelişmiş isterse az gelişmiş olsun, dünyaya yön veren dijital dönüşümü yakalayabilme ve yönetebilme konusunda tüm ülkelerin sorumlulukları; elektronik dünyaya tam anlamıyla dahil olabilmek için teknik altyapı sorunlarını gidermek, politik ve ekonomik destek sağlamak, hukukî çerçeveyi modern dünya gerçekleriyle uyumlaştıracak yasal düzenlemelere yer vermek, sosyo-kültürel boyutta teknoloji 
odaklı eğitim sürecini ve kaliteyi iyileştirmek gibi genel başlıklar altında siralanabilmektedir.

Yeni iletişim teknolojilerini konu alan çalışma bağlamında ele alındığında, bu çok boyutlu düzenlemelerin yetersiz olduğu, bilişim etiği alanında eksikler bulunduğu, bilgi güvenliği ile kişi mahremiyetinin henüz gerçek anlamıyla sağlanamadığı düşüncelerinin ağırlığını koruduğu izlenmektedir. Dolayısıyla bu teknolojilerin kamusal onay alarak toplumsal yaşama dahil olabilmesi için; hukukî, politik ve sosyo-kültürel zeminde gelişmiş düzenlemelere ihtiyaç duyulmaktadır. Böylece gerçekleştirilecek çok boyutlu düzenlemeler ile kişisel haklara ve güvenliğe duyarlı, bilişim etiğine ve mahremiyete önem veren bir toplum yapısı içerisinde, elektronikleşen yaşama dair sorunların giderilmesinde önemli bir aşama kaydedilebileceğini söylemek mümkündür.

\section{KAYNAKÇA}

AKIN, H. Bahadır (2005). Yeni Ekonomi -Strateji, Rekabet, Teknoloji Yönetimi, Konya: Çizgi Kitabevi Yayınları.

ATABEK, Ümit (2006). “İnternette Etik Sorunların Ekonomi Politik Bağlamı”, Küresel İletişim Dergisi,

Say1: 2, Erişim Tarihi: 28.10.2015.

BAUDRILLARD, Jean (2014). Simülakrlar ve Simülasyon, (Çev: Oğuz Adanır), Ankara: Doğu-Batı Yayınları.

BALCI, Ali (2005). Sosyal Bilimlerde Araştırma, Yöntem, Teknik ve İlkeler, Ankara: Pegema Yayıncilik.

BENHABİB, Seyla (2005). Eleştiri, Norm ve Ütopya: Eleştirel Teorinin Temellerine Dair Bir İnceleme, (Çev: İsmet Tekerek), İstanbul: İletişim Yayınları.

BENHABİB, Seyla (1999). Modernizm, Evrensellik ve Birey: Çağdaş Ahlak Felsefesine Katkılar, (Çev: Mehmet Küçük), İstanbul: Ayrıntı Yayınları.

BİNARK, Mutlu ve BAYRAKTUTAN, Günseli (2013). Ayın Karanlık Yüzü: Yeni Medya ve Etik, İstanbul: Kalkedon Yayınları. 
BTK (Bilgi Teknolojileri ve İletişim Kurumu), (2009). "Siber Güvenliğin Sağlanması: Türkiye'deki Mevcut Durum ve Alınması Gereken Tedbirler”, https://btk.gov.tr/File/?path=ROOT\%2F1\%2FDocuments\%2FSayfalar\%2FSi berGuvenlik\%2Fsg.pdf, Erişim Tarihi: 25.01.2017.

CASTELLS, Manuel (1996). The Rise of the Network Society, (The Information Age: Economy, Society and Culture) Vol. 1, USA, MA: Blackwell Publishers, Inc.

ÇALIK, Deniz ve TOKER, Gülben (2016). "Ekran Çağı İnsanı ve Dijital Toplum”, XXI. Yüzyılda Türkiye'de İnternet Konferans1, 03-05 Kasım 2016, Ankara: TED Üniversitesi.

DOLGUN, Uğur (2008). Şeffaf Hapishane Yahut Gözetim Toplumu: Küreselleşen Dünyada Gözetim, Toplumsal Denetim ve İktidar İlişkileri, İstanbul: Ötüken Neşriyat.

ELİBOL, Halil (2005). "Bilişim Teknolojileri Kullanımının İşletmelerin Organizasyon Yapıları Üzerindeki Etkileri”, Selçuk Üniversitesi Sosyal Bilimler Enstitüsü Dergisi, 13, s. 155-162.

ERKAN, Hüsnü (1998). Bilgi Toplumu ve Ekonomik Gelişme, 4. Baskı, İstanbul: Türkiye İş Bankası Kültür Yayınları.

FRIEDMAN, Jack P. (1994). Dictionary of Business Terms, 2nd Edition, New York: Barron's Educational Series.

FUCHS, Christian (2014). Sosyal Medya: Eleştirel Bir Giriş, (Çev: İlker Kalaycı ve Diyar Saraçoğlu), Ankara: NotaBene Yayınları.

GERAY, Haluk ve AYDOĞAN, Aylin (2009). Yeni İletişim Teknolojileri ve Etik, (Editörler), Bülent Çaplı ve Hakan Tuncel. Televizyon Haberciliğinde Etik Sorunlar, Ankara: Fersa Matbaacılık, s. 306-321.

GERAY, Haluk (1994). Yeni İletişim Teknolojileri: Toplumsal Bir Yaklaşım, Ankara: Kılıçaslan Matbaacılık San. ve Tic. Ltd. Şti.

GÜNDÜZ, Uğur ve ENGİN, Yahya (2016). Sosyal Medya ve Dijital Kimlik Olgusu, (Editörler), Ali Büyükaslan ve Ali Murat Kırık. “Göz(@)lenen Toplumdan 
Göz(@)lenen Bireye” Sosyal Medya Araştırmaları 3, Konya: Çizgi Kitabevi, s. $43-60$.

İŞMAN, Aytekin (2016). Bilgisayar Destekli Eğitim Etiği, (Editörler), Aytekin İşman, Hatice Ferhan Odabaşı ve Buket Akkoyunlu. Eğitim Teknolojileri Okumaları 2016, Ankara: Salmat Basım Yayıncılık, s. 73-88.

KUÇURADI, İoanna (2006). Etik, Türk Felsefesi (Simurg Dizisi) Yayınları No: 5, Ankara: Türkiye Felsefe Kurumu.

LYON, David (2006). Günlük Hayatı Kontrol Etmek: Gözetlenen Toplum (Çev: Gözde Soykan), İstanbul: Kalkedon Yayıncılık.

ÖĞÜT, Adem (2001). Bilgi Çağında Yönetim, Ankara: Nobel Yayın Dağıtım.

ÖZÇAĞLAYAN, Mehmet (1998). Yeni İletişim Teknolojileri ve Değişim. İstanbul: Alfa Yayınları.

ÖZKAN, Murat Tolga ve GÜLESİN, Mahmut (2001). "Uzman Sistem Yaklaşımı ile Cıvata ve Dişli Çark Seçimi”, Turkish Journal of Engineering and Environmental Sciences, 25, s. 169-177.

ÖZSUNAY, Ergun (1978). Gerçek Kişilerin Hukuki Durumu, İstanbul: İstanbul Üniversitesi Hukuk Fakültesi Yayınları.

ÖZTEMEL, Ercan (1998). "Bilgi Toplumunda Yönetim Bilişim Sistemlerinin Gelişimi”, Yeni Türkiye Dergisi, 21. Yüzyıl Özel Sayısı II, Yı1: 4, 20, (MartNisan), s. 1175-1181.

KORKMAZ, Ali (2014). "Etik Bağlamda Haber Fotoğrafçılığının Manipülasyon ve Propaganda Aracı Olarak Kullanılmasının Değerlendirilmesi”, Gümüşhane Üniversitesi İletişim Fakültesi Elektronik Dergisi, 2 (4), s. 26-52.

PAVLIK, John V. (2001). Journalism and New Media, New York: Columbia University Press.

PIEPER, Annemarie (1999). Etiğe Giriş, (Çev: Veysel Atayman ve Gönül Sezer), İstanbul: Ayrıntı Yayınları. 
PLOMAN, Edward (1990). İletişim Devrimi Üzerine, (Derleyen), Nabi Avc1. Enformatik Cehalet, İstanbul: Kitabevi Yayınları.

ROBBINS, Robert J. (1992). "Challenges in the Human Genome Project", IEEE Engineering in Biology and Medicine, (March), 11 (1), p. 25-34.

ROBINS, Kevin (2013). İmaj: Görmenin Kültür ve Politikası, (Çev: Nurçay Türkoğlu), İstanbul: Ayrıntı Yayınları.

ROGERS, Everett M. (1986). Communication Technology: The New Media in Society, New York: The Free Press.

SARTORI, Giovanni (2004). Görmenin İktidarı Homo Videns: Gören İnsan, (Çev: Gül Batuş ve Bahar Ulukan), İstanbul: Karakutu Yayınları.

ŞENER, Gülüm ve KUŞ, Oğuz (2015). Büyük Birader’den Büyük Veriye Gözetim Toplumu, (Editör), Özlem Oğuzhan. İletişimde Sosyal Medya Sosyal Medyada Etkileşim, İstanbul: Kalkedon Yayınları, s. 53-82.

TANILIR, M. Niyazi (2002). İnternet Suçları ve Bireysel Mahremiyet, Ankara: Liberte Yayınları.

TBD (Türkiye Bilişim Derneği), (2007). “Bilişsim Teknolojilerinin Kullanılmasının Hukuksal Boyutu 2. Çalışma Grubu Raporu”, Kamu Bilişim Platformu IX, Ankara.

TBV (Türkiye Bilişim Vakfi), (t.y.). "Etik Hakkında, Bilişim Etiği Notları", http://www.tbv.org.tr/turkish/hakkında/etik_k.htm, Erişim Tarihi: 22.11.2015.

T.C. Ulaştırma, Denizcilik ve Haberleşme Bakanlığı, (2016). “2016-2019 Ulusal Siber Güvenlik Stratejisi”, http://www.udhb.gov.tr/doc/siberg/20162019guvenlik.pdf, Erişim Tarihi: 25.01.2017.

TENGİLIMOĞLU, Dilaver ve TUTAR, Hasan (2003). Çağdaş Büro Yönetimi: Büro Yönetiminde Güncel Konular ve Yaklaşımlar, Ankara: Gazi Kitabevi.

TORTOP, Nuri (2000). "Çağımızın Önemli Sorunu: Kişisel Bilgilerin Güvenliği Sorunu", Amme İdaresi Dergisi, 33 (3), s. 1-14.

TUTAR, Hasan (2006). Yönetim Bilgi Sistemi, Ankara: Seçkin Yayıncılık. 
TÜBİTAK (2016). "Bilim ve Teknoloji Yüksek Kurulu (BTYK) 29. Toplantısı Kararları”, https://www.tubitak.gov.tr/sites/default/files/2016_101.pdf, Erişim Tarihi: 28.10.2016.

TÜBİTAK ARDEB-1003 (2015). “Öncelikli Alanlar Ar-Ge Projeleri Destekleme Programı, 2015-2018 Planlanan Çağrılar Kataloğu”, Ankara Teknoloji Transfer Ofisi (Ankara TTO), http://www.ankaratto.com/wpcontent/uploads/2015/05/1003katalog.pdf, Erişim Tarihi: 28.10.2016.

UÇKAN, Özgür (2008). "Bilgi Ekonomisi, Bilgi Toplumu, Mahremiyet ve Güvenlik”, Kişisel Blog, http://ozguruckanzone.blogspot.com/2008/06/bilgiekonomisi-bilgi-toplumu.html, Erişim Tarihi: 17.10.2016.

ULAŞ, Sarp E. vd. (2002). Felsefe Sözlüğü, Ankara: Bilim Sanat Yayınları.

VURAL, Z. Beril Akıncı (2006). Bilgi İletişim Teknolojilerine Genel Bir Bakış, (Editör), Z. Beril Akıncı Vural. Dijital Platform ve İletişim, Ege Üniversitesi İletişim Fakültesi Yayın No: 42, İzmir: Ege Üniversitesi Basımevi, s. 1-25.

WILLIAMS, Anthony (1996). An Introduction to Technology Education, (Editors), John Williams and Anthony Williams. Technology Education for Teachers, South Melbourne, Australia: Macmillan Education, p. 1-26.

YAHYAGİL, Mehmet Y. (2001). KOBİ'lerde Bilgisayar Teknolojileri Uygulamaları, Yayın No: 2001-26, İstanbul: İstanbul Ticaret Odası Yayınları.

YILDIZ, Oktay; DAĞDEVİREN, Metin; ÇETİNYOKUŞ, Tahsin (2008). "İşgören Performansının Değerlendirilmesi İçin Bir Karar Destek Sistemi ve Uygulaması", Gazi Üniversitesi Mühendislik ve Mimarlık Fakültesi Dergisi, 23 (1), s. 239-248.

YÜKSEL, Mehmet (2003). "Mahremiyet Hakkı ve Sosyo-Tarihsel Gelişimi”, Ankara Üniversitesi Sosyal Bilimler Fakültesi Dergisi, 58 (1), s. 181-213.

YÜREGİR, Oya H. ve BABA, Ayça (2004). "Elektronik Ticaret Altyapısında Elektronik Veri Değişiminin (EDI) Yeri ve Türkiye'deki Durum Değerlendirmesi”, Kal-Der Forum, 13, s. 23-27. 